\title{
A propaganda política na construção do imaginário coletivo no cinema de resistência: estudo de caso do filme Jango de Silvio Tendler ${ }^{1}$
}

The construction of propaganda collective imagination in film resistance:

a case study of the film Jango by Silvio Tendler

\section{Adolpho Queiroz}

Professor no Programa de Pós-Graduação em Comunicação da UMESP/SP/BR. adolpho.queiroz@metodista.br

Rose Mara Vidal de Souza

Mestre em Comunicação Social pela UMESP/SP/BR. rosevidal@yahoo.com.br

\begin{abstract}
RESUMO
Este estudo tem como objetivo propor uma análise do modo como se constrói a representação da imagem eleitoral de João Goulart, sob a ótica da propaganda política no cinema brasileiro no período pós-ditadura. Para a realização desse objetivo contamos com o longa-metragem de Silvio Tendler de 1984, intitulado Jango. Cremos que este estudo se justifica por contribuir para identificar, compreender e mapear o imaginário da sociedade brasileira sobre João Goulart. Para o desenvolvimento do tema foram analisadas teorias de marketing político, propaganda ideológica e persuasão. A pesquisa foi norteada pelo método qualitativo e aplicadas as técnicas de pesquisa histórica e estudo de caso. Concluímos que o filme de Silvio Tendler reconstruiu a imagem de João Goulart ressaltando seu papel na luta pelas reformas de base. A mistificação de Jango foi exposta no documentário expositivo.
\end{abstract}

PALAVRAS-ChavE: João Goulart; marketing politico; propaganda política

\section{ABSTRACT}

The objective of my report is to propose an analyses on the way of the election image of João Goulart is built, from the perspective of the political propaganda in the Brazilian cinema of the post-dictatorship. To make it possible, we can rely on the film Jango, form Silvio Tender, 1984. We believe that this report is able to contribute with the process of identification, understanding and learning about the Brazilian society ideas about João Goulart. To develop this issue we had to analyze theories related to political marketing, ideological advertisement and persuasion. The research was based on the qualitative and quantitative methods, techniques of historical research and case studies. We got to the conclusion that the film reconstructed Joao Goulart's image, focusing on his attitudes towards the basic reforms. Jango's mystification was shown in a documentary.

KEYWORDs: Joao Goulart; political marketing; political advertising 
contextualização histórica do Brasil nas décadas de 1950 e 1960 até o início da ditadura em A1964 é uma tradução de efervescência política e econômica. É neste cenário tão rico de anseios por mudanças que é narrado o filme de João Goulart, uma personalidade enigmática da história brasileira. Herdeiro do mito Getúlio Vargas e vice-presidente de outro titã, Juscelino Kubitschek, Jango utilizou o populismo como mola propulsora para sua ascensão eleitoral, porém os fracos desempenhos da sua propaganda política e de seu espírito de liderança fizeram-no naufragar, culminando sua trajetória no golpe militar de 1964.

Um dos documentos que permanece vivo sobre a imagem de João Goulart é o documentário de Silvio Tendler, intitulado Jango - Como, quando e porque se derruba um presidente, de 1984. O longa metragem de quase duas horas (117 minutos) narra a carreira do rapaz que saiu dos pampas para ser presidente do Brasil. Um percurso que começou aos 28 anos, quando, a convite e por insistência de Vargas, concorreu a uma cadeira na Assembléia Legislativa do Rio Grande do Sul. Ele foi eleito com 4.150 votos, tornando-se o quinto candidato mais votado, a frente de seu cunhado Leonel Brizola (casado com sua irmã Neusa até a morte dela em 1993), outra estrela em ascensão do PTB.

A imagem pública de Jango para quem o desconhece é uma e a partir do documentário de Tendler passa a ser outra. Um filme que remonta o contexto histórico político da pré-ditadura, lançado durante o processo de redemocratização do país. O cinema, que é uma ferramenta poderosa da propaganda política, é analisado neste artigo como instrumento para um imaginário coletivo.

O objetivo central deste estudo é entendermos como o cinema pode contribuir para a disseminação da propaganda política e do imaginário coletivo.Busca-se ainda analisar a imagem pública de João Goulart retratada pelo filme Jango, de Silvio Tendler. Como o estudo foi norteado do ponto de vista da comunicação política, analisamos as estratégias da propaganda política, ideológica e do imaginário coletivo mostradas no filme e também utilizadas na construção do roteiro do mesmo.

Considerando que o estudo proposto busca obter informações de natureza histórica, a fim de poder identificar a imagem pública refletida pelo documentário Jango, partindo do prisma do emissor, ou seja, do diretor, foi adotado, por força de suas características tipológicas e metodológicas, a pesquisa qualitativa como método. O objetivo é verificar como a imagem de João Goulart aparece em cada cena do referido filme, comparando com os embasamentos teóricos existentes. 


\section{Imaginário e política}

A palavra política fomenta na cabeça do indivíduo, dependendo do país em que vive, um tipo de imaginário. Apesar de aparecer no dicionário como: 1. arte ou ciência de governar; 2 . arte ou ciência da organização, direção e administração de nações ou Estados ou ainda 3. a aplicação desta arte nos negócios internos da nação (política interna) ou nos negócios externos (política externa); no Brasil, por exemplo, a palavra 'política' vem arraigada à corrupção, desonestidade e a outras conotações negativas.

Esse imaginário não surge "do nada" na mente da pessoa, mas literalmente brota. Para este conceito negativo desenvolver-se foi semeado "algo" no inconsciente do indivíduo, cultivado com muita intensidade. Quando se fala em imaginário se atrela ao falso, ao fantasioso. Porém, o imaginário vai alémdisto e gera várias definições por diferentes autores. Deleuze (1992) aponta autores como Bachelard que afirma que o imaginário é nossa válvula de escape, nossa abertura para outras sensações. Já para Le Gof o imaginário, apesar de estar na área da representação, vai além disto, pois cria, tangido poeticamente, dando toques particulares a esta representação.

Segundo Castoriadis (1995, p. 177) o imaginário se define pela imagem que os indivíduos e os grupos sociais têm do mundo, dos objetos e dos seres que compõem este mundo, bem como a imagem que fazem de si mesmos, de suas necessidades, de suas finalidades e de seus valores.

A instituição, conforme assinala Castoriadis, é uma rede simbólica definida socialmente, que contém os componentes organizador e do imaginário. O conceito de imaginário em Karl Marx explica, através da noção de alienação, a autonomia das instituições econômicas ou religiosas como produtos independentes das ações humanas, expressando as contradições reais entre o produtor e o produto que passa a ser reificado. $O$ imaginário seria, então, a solução fantasiosa das contradições reais (Laplantine; Trindade, 1996, p. 7).

Em uma última tentativa de apresentar esta gama de conceitos sobre o imaginário e ao que vai a encontro dos nossos pensamentos, citaremos Durand (1997, p. 14) que afirma que o imaginário é o "conjunto das imagens e das relações de imagens que constitui o capital pensado do homo sapiens", é a recriação das relações inexistentes no mundo real que é captada e estimulada neste imaginário. Durand discorda de Lacan, que afirma que o imaginário resume-se a experiências individuais e fraudulentas, enquanto simbólico seria coletivo e cultural. 
66 O imaginário não só se manifestou como atividade que transforma o mundo, como imaginação criadora, mas sobretudo como transformação eufêmica do mundo, como intellectus sanctus, como ordenança do ser às ordens do melhor (Durand, 1997, p. 432).

Este imaginário social é que dá o tom na política. Neste jogo outros ingredientes se misturam para dar o tempero da disputa política: os mitos, os arquétipos, a propaganda persuasiva, a ideologia e a exploração do inconsciente coletivo.

\section{Cinema e propaganda política}

Falar de cinema e falar de imaginário social se torna quase verossímil. O cinema é uma fábrica de sonhos, desejos, buscas. Apesar dos adventos da vida moderna, o cinema continua com seus adeptos aficionados. Através da telinha mágica a vida se torna palpável e numa pseudorrealidade conseguimos dar forma a olhares deste e de outros mundos.

De acordo com Souza (1981), por incrível que pareça o cinema chegou ao Brasil um ano depois.A primeira exibição de cinema em terras tupiniquins aconteceu na rua do Ouvidor, no 57, no Rio de Janeiro, em 8 de julho de 1896. No ano seguinte, inaugurou a primeira sala fixa, também na rua do Ouvidor, no Rio de Janeiro.

Não demorou muito para o cinema ganhar adeptos mundo afora, o cinema se tornou mais que uma opção de entretenimento, se tornou uma mercadoria. O cinema, ao contrário do DVD, Cd ou livro, é uma mercadoria perecível. Você compra o ingresso utiliza ou não e nunca mais vai usar esse. Como se fosse um bilhete único e intransferível. Acoplado a esta característica, o cinema gera muito mais lucro, que o teatro, por exemplo, pois é através da reprodução de cópias que se expande mundialmente. Os produtores da indústria cinematográfica, antes do fim da primeira década do século $\mathrm{XX}$, ao invés de alugarem as cópias dos seus filmes aos exibidores, eles as vendiam. Os produtores perceberam que teriam mais lucro recebendo porcentagem em cima do número de vezes que o filme fosse exibido.

Segundo Bernadet (1988, p. 12) na década entre 1910 e 1930 os filmes nacionais eram produzidos esporadicamente, sempre com história em atos e figuras "heróicas". O primeiro político brasileiro a utilizar o cinema como propaganda persuasiva, de forma mais consistente, foi Getúlio Vargas com os Cinejornais periódicos que exibia nas salas por todo o país. 
A filmagem, a montagem, a música e o discurso apresentados nos cinejornais que traziam os comícios, veiculados nas salas de cinema antes da exibição dos filmes, eram minuciosamente articulados para que a imagem de 'pai dos pobres' fosse fomentada, sendo que em todas as produções, inclusive na época em que a veiculação dos cinejornais era obrigatória e coordenada pelo DIP (Departamento de Imprensa e Propaganda), Vargas estava cercado pela população que o aplaudia e gritava seu nome (Rocha e Franco, 2007, p. 35).

As imagens dos cinejornais exaltavam a emoção e gratidão do candidato frente a sua aceitabilidade do povo, assim como a música que instigava o nacionalismo e o crescimento econômico do Brasil, que poderia se tornar um dos melhores lugares para se viver. Notamos aí a semelhança com outros filmes lançados no exterior, como o da campanha nazista e algumas milhares de dezenas de filmes hollywoodianos.

Estes últimos com menções de bandeiras e outros símbolos nacionais em quase todos os filmes originários dos EUA levando os espectadores a um condicionamento da terra prometida, da "América perfeita". Fator explicado pelo microbiologista russo Serge Tchakhotine que relacionou o êxito da propaganda nazista através da interpretação da teoria dos reflexos condicionados de Pavlov. Esta técnica também foi utilizada por Mussolini que dominava de longe um "condicionamento das massas". Vale ressaltar que condicionamento, para que sempre surta o efeito desejado, tem que ser repetido de tempos em tempos para que não caia no esquecimento.

A explicação do fato de que os movimentos políticos atuais se servem particularmente dos símbolos para seu recrutamento e sua ação não representa dificuldades. A história nos fornece, aliás, exemplos magníficos do seu emprego eficaz: a progressão triunfal do símbolo cristão - a Cruz; as letras S.P.Q.R., velho emblema do poder de Roma, o Crescente do Islã, etc. Um exemplo de luta política, por meio de símbolos, nos dá o passado: a luta entre a Cruz e o Crescente (Tchakhotine, 1967, p. 259).

A propaganda política e ideológica presente nos filmes permite disseminar, de forma persuasiva, para toda a sociedade as ideias de determinado grupo. Depois de emitida através de diversos meios e suportes de comunicação, elas passam a ser retransmitidas, direta ou indiretamente, no seio das diversas instituições sociais, ampliando e reforçando o processo de difusão. 
66 A ideologia, dessa forma, se espalha e impregna todas as camadas da sociedade. Na família, na escola ou no trabalho, em todas as partes e por todos os meios, todos passam a ser orientados para os mesmos fins e enquadrados dentro dos mesmos princípios (Garcia, 1992, p. 78).

O cinema, como dito anteriormente, faz essa junção do áudio, do visual e da fascinação. A luz baixa, o silêncio, as pessoas reunidas é como um ritual para aceitação da mensagem. E a política, onde o poder está intrínseco, se rodeia dessas representações coletivas, onde o domínio do imaginário e do simbólico é um importante lugar estratégico.

De acordo com Baczo (1985), exercer um poder simbólico não consiste meramente em acrescentar o ilusório a um potencia "real", mas sim em duplicar e reforçar a dominação efetiva pela apropriação dos símbolos e garantir a obediência pela conjugação das relações de sentido e poderio.

Mas nem sempre é a visão dos partidos que é repassada nos longas, a visão do diretor ou da população também pode afetar a produção e a construção desses imaginários coletivos. Os documentários, por exemplo, refletem muito o contexto e a visão do diretor sobre o tema. Que Bernardet (1985) complementa dizendo que além dos mecanismos que vimos para significar o real, o filme se vale de outro: o encadeamento das sequências num raciocínio lógico que mistura a análise do fenômeno com o contexto inserido. $\mathrm{O}$ documentário é um gênero cinematográfico que se caracteriza pelo compromisso com a exploração da realidade. Mas dessa afirmação não se deve deduzir que ele represente a realidade "tal como ela é". O documentário, assim como o cinema de ficção, é uma representação parcial e subjetiva da realidade.

66 A ideia é que, ao vermos um documentário, em geral temos um saber social prévio, sobre se estamos expostos a uma narrativa documental ou ficcional. Como espectadores, fruímos a narrativa em função deste saber prévio, presença do passado no presente imediato [...]. Na ampla maioria dos casos, efetivamente, sabemos o que significa uma narrativa documental, que tipo de imagens contém, e reagimos, enquanto espectadores, a este saber. Socialmente, uma série de procedimentos nos informa o tipo de narrativa a que estamos tendo acesso (D'Almeida apud Ramos, 2001, p. 199-200).

Ainda de acordo com D’Almeida (2006) existem seis modos de se fazer documentários: poético, expositivo, observativo, participativo, reflexivo e performático. O filme Jango de Silvio Tendler 
pode ser descrito como uma combinação dos modos expositivo e participativo, ressaltando este último modo que caracteriza, segundo estudos de Bill Nichols, os telejornais e as reportagens investigativas.

O modo expositivo "agrupa fragmentos do mundo histórico numa estrutura mais retórica ou argumentativa do que estética ou poética", com legendas ou vozes que "propõem uma perspectiva, expõem um argumento ou recontam uma história"(Nichols, 2005, p. 142). Também de acordo com Nichols (2005), a voz do narrador é um show a parte. Com discursos objetivos, prende a atenção do telespectador combinando seu tom e volume da voz com as imagens. Semelhante aos âncoras de noticiários televisivos, o narrador do documentário expositivo passa credibilidade, segurança e neutralidade.

O modo participativo, por sua vez, deixa clara a interferência do cineasta na realidade que pretende registrar. $\mathrm{O}$ mundo histórico é representado por alguém que nele se engaja ativamente, colocando o cineasta em cena. Esse estilo de filmar é o que Rouch e Morin denominaram de cinémavérité.

$66[$ [...] Como cinema verdade, a ideia enfatiza que essa é a verdade de um encontro em vez da verdade absoluta ou não manipulada. Vemos como o cineasta e as pessoas que representam seu tema negociam um relacionamento, como interagem, que formas de poder e controle entram em jogo e que níveis de revelação e relação nascem dessa forma específica de encontro (D'Almeida apud Nichols, 2005, p. 155).

Para dar mais credibilidade e a função de isenção, o cineasta utiliza entrevistas para unir vários depoimentos numa única história. Então o documentário é contar uma história, geralmente do passado, e aí fica evidente a subjetivação do cineasta e sua impressão ao remontar esses fatos.

\section{Análise e discussão do documentário Jango}

O filme Jango é uma remontagem dos fatos que antecederam sua deposição pelo golpe de 1964 . Silvio Tendler começa o longa na viagem de Jango à China, quando foi pego de surpresa pela notícia da renúncia do presidente Jânio Quadros. A partir daí vai-se desenrolando uma narrativa exploratória, entremeada de depoimentos de personalidades da época que testemunharam seu governo. 
O cerne do documentário está cravado nas lutas sociais lideradas por João Goulart. Relatando sua biografia desde o ingresso precoce na política do Rio Grande do Sul até o desfecho trágico com sua morte no Uruguai. A narrativa menciona a aproximação de Jango com Getúlio Vargas, como seu articulador no segundo mandato e, posteriormente, como Ministro do Trabalho do seu governo. Aqui é claro a intersecção da busca pelo honorífico, citado por Veblen (1983), onde o homem persiste com muita força a distinção teórica arcaica do troféu. Se ele não o possui, é vantajoso estar ao lado de quem o possui. Com relação à ascendência de Goulart em ter uma família abastarda oriunda do Rio Grande do Sul, pode-se remeter ao pensamento de Veblen que pontua esta situação como um sinal específico da classe ociosa, que por si já nasce com o papel de liderança na sociedade e que servirá de espelho para os mais pobres um dia serem como eles.

Tanto o ócio como a propriedade são elementos da estrutura social, são fatos convencionais.

$66[\ldots]$ Não se deve esquecer naturalmente que, numa comunidade em que praticamente todos os bens são de propriedade privada, a necessidade deganhar a vida é um incentivo poderoso e onipresente para os seus membros mais pobres. [...]. A propriedade surgiu e se tornou uma instituição humana sem relação com o mínimo de subsistência. O incentivo dominante desde o início foi a distinção odiosa ligada à riqueza; exceto temporária e excepcionalmente, nenhum outro motivo se lhe sobrepôs em qualquer estágio posterior de desenvolvimento (Veblen, 1983, p. 15-17).

Frases de efeito do narrador José Wilker, por exemplo: "Jango propunha o fim da fome e da miséria num país em que a injustiça sempre foi o lado obscuro da democracia" (Jango, $1984,117 \mathrm{~min})$. Nesta parte quase não existe trilha sonora no filme, apenas narração e imagens que retratam o discurso de Jango em defesa da democracia e da justiça social. Esta imagem de "salvador da pátria" e o arquétipo de herói é recorrente em todo o documentário. Segundo Jung (2008), dentro do inconsciente coletivo existem estruturas psíquicas ou arquétipos que funcionam como uma espécie de canalizador do material psicológico. Como fôrmas pré-moldadas. Nosso inconsciente coletivo na área da política, principalmente quando o país não vai bem, "persegue" o candidato que mais se assemelha ao que vai restabelecer a harmonia econômica e social para aquele povo. Assim aconteceu com Vargas e depois com Goulart, que conseguiu a simpatia das massas operárias. 
Os entrevistados do documentário em voga compõem uma história linear e subjetiva da visão do autor, ressaltando a imagem de Jango como um possível sucessor de Getúlio Vargas e JK. Em quase todo o filme, Jango aparece sorrindo com crianças em volta e ao lado da população trabalhadora, com um discurso sempre voltado para os operários. Somente no penúltimo take, quando começam as imagens sobre o golpe e o início da ditadura é que Jango muda sua feição, passando a ter um rosto compenetrado e triste. A partir daí nota-se a importância da persuasão e da propaganda ideológica aliada à retórica. "Desse modo é evidente que se a política necessite de uma ars ou téchné - isto é, de uma destreza que a auxilie na consumação dos seus propósitos, normalmente não recorre à poética, mas a retórica". É mais civilizado resolver os "problemas pela força do discurso do que pela força bruta" (Gomes, 1995, p. 73).

A partir daí a música Coração de estudante de Milton Nascimento, em versão instrumental, é ouvida, sem narração, apenas com as imagens de Goulart em sua granja em São Borja (RS), com cabeça baixa, caminhando sozinho numa estrada cheia de árvores em volta. Com base nesta observação, faz-se uma ponte entre esta cena do filme e a afirmação de Castoriadis (1995) que diz que em todas as sociedades existe uma representação de si mesma com "alguma coisa". A exemplo do povo brasileiro que tem uma identidade hospitaleira e emocional. Conforme esta cena descrita acima o imaginário coletivo é de melancolia e de tristeza. A simbologia é em torno de um líder abandonado injustamente por cuidar do povo (Cunha, 1997, p. 1).

A seqüência do longa metragem fica por conta de outros exilados e mortos pela ditadura na América Latina, incluindo Che Guevara e o senador chileno Salvador Allende. As cenas de Che morto têm a duração de quase 5 minutos. Após isto, as imagens são da violência na ditadura, estudantes espancados, passeatas e a história dos atos institucionais $\mathrm{n}^{\circ} 2$ e $\mathrm{n}^{\circ}$ - . A sensação é de agonia e de injustiça. O simbolismo contido nestes takes é carregado de ideologia e referências de dor e angústia. O imaginário descrito neste filme não é apenas a cópia do real, o seu viés simbólico amplia os sentidos em imagens expressivas. "O real não é só um conjunto de fatos que oprime, ele pode ser reciclado em novos patamares" (Moraes, 1994, p. 39).

A rede imaginária possibilita-nos observar a vitalidade histórica das criações dos sujeitos - isto é, o uso social das representações e das ideias. Os símbolos revelam o que está por trás da organização da sociedade e da própria compreensão da história humana. A sua eficácia política vai depender da existência daquilo que Backzo chama de comunidade de imaginação ou comunidade de sentido. As significações imaginárias despertadas por imagens determinam 
referências simbólicas que definem, para os indivíduos de uma mesma comunidade, os meios inteligíveis de seus intercâmbios com as instituições. Em outras palavras: a imaginação é um dos modos pelos quais a consciência apreende a vida e a elabora. A consciência obriga o homem a sair de si mesmo, a buscar satisfações que ainda não encontrou (Moraes, 1994, p. 39).

A seguir aparece Jango no exílio no Uruguai. O narrador diz: “O presidente não conseguia nem se animar com o aniversário da própria filha". A cena é coberta por um close em uma foto de aniversário de sua filha Denize Goulart. A câmera sobe e mostra um Jango novamente triste e com a cabeça baixa. Mais uma vez o filme chama a atenção para o sofrimento do expresidente. Esta cena pode ser entendida como artifícios do marketing político, misturando propaganda política, imaginário coletivo, persuasão e ideologia, todos unificados como o magma dos arquétipos, da mitologização, do simbolismo e estereótipos. Segundo Queiroz (2007), é através do marketing político que os partidos podem disseminar conteúdos e emoções através dos meios de comunicação.

O filme ressalta ainda que o populismo de Getulio Vargas passou a ser símbolo da política de manipulação de massas, e aqueles que herdaram os principais aspectos do varguismo eram vistos com maus olhos por grande parte da elite nacional, que tinha aversão à ampliação da democracia brasileira e à inserção da classe trabalhadora no jogo político. O simbolismo em torno do populismo é um fato consumado. São dois imaginários em torno dos governos populistas: o de paternalista e o de estar ao lado do povo. A discussão é extensa e não cabe nesta pesquisa definir ou optar por esta ou aquela conceituação. No entanto, de acordo com o filme, o sentindo de populismo tem o sentido de "estar ao lado do povo", conforme confirmado pelo próprio diretor Silvio Tendler em entrevista concedida aos autores.

Após seguir os passos de Vargas, as virtudes de Goulart seriam reconhecidas. Ele foi eleito duas vezes para vice-presidente. No documentário há um grande destaque para a preocupação com o povo, que o filme afirma ser maior que a preocupação pessoal. "Não me importo em cair, mas caio de pé. Eu preciso realizar essas reformas" (Jango, 1984, 117min). A observação das classes sociais em evidência faz parte da propaganda política e ideológica. Segundo Garcia (1982), uma classe social se constitui de pessoas que ocupam um mesmo espaço no plano de produção econômica.

No sistema capitalista a sociedade é dividida em dois blocos fundamentais: os trabalhadores e os patrões. Os operários entram com a força do seu trabalho e ganham apenas para sobreviver, 
enquanto os patrões administram o dinheiro e o poder. Assim a classe menos favorecida é apenas sujeita a decisões tomadas pela segunda classe, onde se enquadram também os órgãos governamentais. A vantagem do patronato é deter o capital, as terras, as máquinas e as ferramentas, garantindo assim o sucesso sobre esses órgãos e maior influência sobre eles, já que os mesmos ajudam a financiar vários projetos.

Ainda de acordo com Garcia (1982), os limites que definem os espaços das classes sociais não são estáticos, nem eternos. Uma classe ou apenas um grupo contido nela pode ampliar seu campo de ação. O número de trabalhadores é um exemplo disto, o próprio sistema capitalista exige uma maior demanda de mão-de-obra. Outro fator que interfere diretamente nas classes sociais é a qualificação profissional. Com os avanços tecnológicos o mercado exige cada vez mais trabalhadores qualificados, assim, consequentemente, o nível intelectual da massa proletária avança podendo compreender melhor sua situação e perceber a contradição entre o baixo nível salarial e os altos lucros das empresas. Com isso o diálogo entre esta classe vai gerar um movimento organizado, dando origem a sindicatos ou mesmo partidos políticos. Como pensou Marx:

66 Os comunistas diferenciam-se dos outros partidos proletários apenas em dois pontos: de uma parte, nas diversas lutas nacionais dos proletários, fazem prevalecer os interesses da nacionalidade; de outra parte, nos diversos estágios de desenvolvimento da luta entre proletariado e burguesia, representam sempre o interesse do movimento geral (Marx, 1996, p. 75).

A percepção de Goulart para esta classe de operários foi vital para sua consolidação política. As longas imagens contidas no filme (analfabetos, trabalhadores rurais e operários) sem narrativa e sem trilha sonora se transformam em discurso ideológico.

A primeira delas é do comercial exibido pela televisão IPES (Instituto de Pesquisa e Estudos Sociais) fundado pelo general Golbery do Couto e Silva, prócer do golpe e ideólogo do governo militar. Em outra, são inseridas cenas do filme Encouraçado Potemkin, de Sergei Eisenstein, com imagens da revolta dos marinheiros de 1964 (D'Almeida, 2006, p. 7)

O final do filme é dramático. O enterro do estudante Edson Luís, morto pela ditadura, a cena com a multidão pedindo justiça e o fechamento do Congresso é a próxima sequência que daria espaço para o fulminante ataque cardíaco de João Goulart no Uruguai. Novamente, agora moça, a sua filha Denize Goulart, diz que o maior sonho do pai era voltar ao seu país. Os 
carros atravessando a ponte em direção ao Brasil sugerem que ele voltou, só que morto. $\mathrm{O}$ túmulo do ex-presidente encerra o documentário com um poema do compositor Fernando Brant. Fernando Brant, Milton Nascimento e Vagner Tiso estiveram entre as figuras da campanha pela redemocratização no país no início dos anos 1980.

66 Os acontecimentos daqueles dias

ainda estão claros na memória:

fechado no escuro do quarto,

querendo fugir do mundo

que me chegava pelo rádio,

eu, pouco mais que um menino,

chorava, como se fosse morte,

a viagem-fuga do Presidente Jango.

Os anos passados, a maturidade

e a visão diária da injustiça e do ódio, da opressão, da mentira e do medo,

me leva agora, adulto, em nome da verdade e da história,

a reafirmar o menino:

as lágrimas derramadas em 64

continuam justas.

O filme de Tendler funcionou como instrumento de contrapropaganda política, conforme Domenach. Garcia compartilha esta ideia. “Quando não conseguem obter monopólio das informações através do controle ideológico, os grupos procuram neutralizar as ideias contrárias através da contrapropaganda" (Garcia, 1982, p. 60).

A discussão de um tema que incomodava o regime militar na época funcionava como esclarecimento às novas gerações e de estímulo cultural àqueles que participavam intensamente dos movimentos políticos que posteriormente acabariam com a ditadura militar no Brasil. Os números da audiência do documentário Jango, tanto no circuito comercialcomo em cineclubes de estudantes, de diretórios acadêmicos, confirmam a oportunidade de realização do filme. O sucesso que obteve com o público o transformou num instrumento de contestação e,especialmente, de resistência ao regime militar. 


\section{Considerações finais}

Jango teve sua vida marcada por dois grandes mitos, trabalhou nos governos de JK e Getúlio Vargas. A herança populista marcada e enfatizada no filme de Silvio Tendler resgata a tentativa de torná-lo também um mito. Assim como um produto, o candidato é apresentado ao seu eleitorado. No caso de Goulart, mesmo depois de morto, sua imagem foi reconstruída no filme, que bateu recordes de público. O marketing político trabalha exaustivamente isso, conforme podemos verificar ao longo deste artigo, desde os tempos da segunda guerra mundial até a indústria cinematográfica hollywoodiana.

A propaganda política usada no cinema nas décadas de 1930 a 1960 destacou os arquétipos do "herói". Era comum o cinema nazista, fascista e norte-americano utilizaros longas metragens para persuadir e disseminar a ideologia partidária.

Durante a Segunda Guerra Mundial foram produzidos diversos filmes dedicados à glorificação do soldado e à exaltação da preparação bélica das forças armadas: Squadrone bianco (1936), de Augusto Genina, tinha como protagonistas os soldados italianos que lutavam na Líbia; Luciano Serra pilota (1938), de Goffredo Alesandrini e Vittorio Mussolini, exaltava heroísmo dos aviadores italianos através das aventuras do piloto Luciano que, durante quase 15 anos após o final da Primeira Guerra Mundial, desafiando o desejo dos seus pais, vive como um aventureiro da aviação, atuando em números aéreos circenses na América do Sul (Pereira, 2003, p. 108).

Estas fórmulas foram reaplicadas em diversos governos ao redor do mundo. Mas salientamos que não foi exclusividade dos países participantes da Segunda Guerra, como sabemos desde os tempos de apogeu da civilização egípcia, passando pelo império romano e caindo no reinado de Luís XIV, que a propaganda política utiliza imagens. "Julio César fazia afixar certas notícias nas paredes do Forum, mas circulava uma versão bem diferente entre os membros da classe governante" (Brown, 1976, p. 17).

Peter Burke (1994), em seu livro "A fabricação do rei", explica o funcionamento da máquina de propaganda de Luis XIV, que foi surpreendente para sua época (século XVII). Burke narra como a construção da imagem pública é oriunda da junção da arte e do poder para aquele rei e da manipulação dos canais de comunicação (oral, visual e escrito) e seus códigos (literários e artísticos), além do público alvo e sua reação a tal massacre publicitário. "As grandes somas de dinheiro e os cuidados empregados na fabricação da imagem pública de Luís XIV o transformaram 
numa criatura dotada de poderes divinos" (Burke, 1994, p. 21). A propaganda política fomentou o imaginário coletivo que o "Rei Sol" ocupa até hoje.

Os políticos desde outrora sempre desejaram isto e não se importam em serem produtos. A comunicação, quando destinada a produto, faz valer sua condição de produção simbólica por excelência, pois agrega a um bem material valores, sentimentos, sonhos, fantasias, enfim, a dimensão imaterial que promove a diferenciação. Como sugere Claude Hopkins (1966, p. 110):

66 Tentamos dar a cada anunciante um estilo apropriado. Tornando-o distinto, talvez não em aparência, mas em maneira e tom. É lhe dada uma individualidade que melhor convenha às pessoas a que se dirige.

E isso é exatamente o que ocorre na prática do marketing político e na propaganda política.A população precisa ver o candidato como um benfeitor que esteja atento as suas angústias e desejos. Veblen (1983) discorre sobre isso em seus estudos, dizendo que o homem sempre persegue o honorífico, mesmo que esse não o detenha; ele quer estar sempre ao lado de quem possui o honorífico - o vencedor, o guerreiro, o herói, aqui representado pelo candidato mais forte/qualificado. Essas simbologias, conceituadas por Jung como arquétipos, vivem no nosso inconsciente e nos remetem aos anseios mais profundos. $\mathrm{O}$ marketing apropria-se dessa condição como mola propulsora para determinar nossas satisfações. Quem não quer eleger um candidato que vai amparar e proteger a todos? Isso contempla o arquétipo do grande pai, aliado ao do herói, que remete ao modelo mental tornando visível, real e factível.

A aproximação de Goulart com os sindicatos de trabalhadores urbanos, que era uma orientação de Vargas, garantiu-lhe uma base sólida de sustentação tanto para conferir-lhe legitimidade na arena política, quanto serviam como foco irradiador de propaganda e aliciador de militantes. Os trabalhadores foram o grande alvo das iniciativas persuasivas em todos os âmbitos da comunicação -midiática massiva e/ou interpessoal.

No Brasil do século $X X$, ocorreram pelo menos três momentos de aproximação entre as técnicas da propaganda política fascista e governos/governantes dos respectivos períodos: no Estado Novo, com Getúlio Vargas; na ditadura de 1964-1985, com os governos militares; e, mais recentemente, no anos 1990, com Fernando Collor de Melo. 
66 Se, por um lado, Getúlio Vargas criou a figura do 'marmiteiro', trabalhador que levava de comida de casa para o trabalho, e através desta imagem mandou cunhar milhares de broches de lapela para distribuir em suas campanhas eleitorais.[...] A exploração de símbolos abstratos e fortes, como 'marmiteiros' e 'marajás', surge na esteira de criações das imagens do fascismo, como se fossem os camisas-pretas a serviço de Mussolini para espancar, inspirar ódio pelo diferencial que representavam (Queiroz, 2004, p. 66).

Outra estratégia de simbologia do governo de João Goulart foi ligá-lo às reformas de base. Como o sucesso das leis trabalhistas, enquanto estava como Ministro do Trabalho no governo de Vargas, que deu impulso a Jango continuar a luta por essa bandeira. O grande problema, segundo o filme de Tendler, é que Goulart não tinha espírito de liderança, nem era tão forte politicamente como JK e Vargas. E um mito se constrói com vários ingredientes que ele acabou não tendo.

Os ataques constantes de seus adversários surtiram efeito e Jango não teve "pulso" o suficiente para manter a postura de "herói" e "pai dos pobres", imagem esta que o ex-presidente da República Luiz Inácio Lula da Silva incorporou tão bem. O propagandista freqüentemente procura influenciar seu público pela substituição de termos favoráveis ou desfavoráveis, com uma conotação emocional. Ao invés de serconhecido como o sucessor do "pai dos pobres", os adversários de Jango divulgavam o nome de "vermelho" para comunista e subversivo.

A dedução dessas diferenças não-existentes e o exagero do significado de pequenas diferenças de fatos existentes culminaram no fracasso político de Jango e o filme sobre sua vida política, apesar de tentar mistificar, apresenta estes fatores.

O documentário de Tendler é uma prova importante da reconstrução de uma imagem política e sua tentativa de transformá-la em um mito. A luta de classes, o bem contra o mal, arquétipos e estereótipos que envolvem todo o processo do cinema e da política. A compreensão e a apreensão dessas contribuições teóricas ampliam o poder de persuasão, envolvimento e sedução marcado nas mensagens emitidas sobre os eleitores, confirmando suas identificações com os candidatos. Afinal, o processo de personificar candidatos/produtos, como reflexo de nossos próprios desejos, responde às nossas incertezas e cria vínculos emocionais não só na área material, mas também na área psíquica, por meio da mitologização do candidato. 
Apesar de João Goulart não ter conseguido a mistificação, o documentário de Tendler demonstra que os filmes refletem as correntes e atitudes existentes numa determinada sociedade. O cinema é afetado pelo contexto político, social e econômico da época e a visão do seu diretor é inconsciente ou consciente, exposta ou escondida no roteiro do longa metragem sobre vida e obra do homenageado.

O cineasta Silvio Tendler insere-se no panorama contemporâneo da produção de reflexão sobre a política no Brasil com um conjunto de obras que perpassa os ex-presidentes João Goulart, JK e Jânio Quadrosabsolutamente necessário a todos aqueles que se interessem pelo desenvolvimento e aperfeiçoamento do Marketing Político no Brasil. Visto com os olhos de hoje o filme Jango é o retrato objetivo de uma época de lutas que culminaram com a consolidação do processo democrático no Brasil e deixaram para trás as longas noites de uma ditadura que não se deseja mais, mas cujas contradições não podem ser deixadas de lembrar. Com narrativa detalhada daquele período, Tendler prenuncia a chegada dos novos tempos do Brasil democrático.

Com a leitura crítica que desenvolvemos a partir deste filme, deixamos mais estacontribuição ao projeto de pesquisa Propaganda Política no Brasil Republicano da UMESP, com a expectativa que outros autores enxerguem no cinema uma forma de manifestação igualmente importante como tem sido até aqui o jornalismo impresso, o rádio, a televisão e, mais recentemente, a internet. $\mathrm{O}$ cinema tem uma contribuição histórica relevante para a difusão da propaganda política no Brasil contemporâneo.

\section{NOTA}

1 Dissertação de Mestrado defendida no curso de Comunicação Social da Universidade Metodista de São Paulo.

\section{REFERÊNCIAS}

BACZO, Bronislaw. Aimaginação social In: LEACH, Edmund et al. Anthropos-Homem. Lisboa Nacional/Casa da Moeda, 1985.

BERNARDET, Jean-Claude. O que é cinema. 3. ed. São Paulo: Brasiliense, 1981.

. Cineastas e Imagens do povo. São Paulo: Brasiliense, 1985. 
BERNARDET, Jean-Claude; RAMOS, Alcides Freire. Cinema e história do Brasil. São Paulo: Ed. Contexto, 1988.

BROWN, J.A.C. Técnicas de Persuasão: da propaganda à lavagem cerebral. Trad. Octavio Alves Velho. Rio de Janeiro: Jorge Zahar, 1976.

BURKE, Peter. A Fabricação do Rei: a construção da imagem pública de Luís XIV. Rio de Janeiro: Jorge Zahar, 1994.

CASTORIADIS, Cornelius. A instituição imaginária da sociedade. 3. ed. Rio de Janeiro: Paz e Terra, 1995.

CUNHA, Magali do Nascimento. Crise, Esquecimento e Memória. O Centro Ecumênico de Informação e a construção da identidade do Protestantismo Brasileiro. 1997. Dissertação (Mestrado em Memória Social e Documento) - Universidade do Rio de Janeiro. Rio de Janeiro, 1997.

D’ALMEIDA, Alfredo Dias. De Jango, de Sílvio Tendler, a Salvador Allende, de Patricio Guzmán, o documentário como ferramenta para a construção de memórias adormecidas. Artigo apresentado no UNESCOM: Congresso Multidisciplinar de Comunicação para o Desenvolvimento Regional, 2006. Disponível em: <http://encipecom.metodista.br/mediawiki/ images/c/cd/GT5_CELACOM_06_De_Jango_Alfredo.pdf >. Acesso em: 03 fev. 2011.

DELEUZE, Gilles. Conversações. Rio de Janeiro: Editora 34, 1992.

DOMENACH, Jean-Marie. A Propaganda Política. E-book, 1963. Disponível em: <http://www.ebooksbrasil.org/eLibris/ proppol.html>.

DORIN, Lannoy. Psicologia geral. São Paulo: Livraria Iracema, 1987.

DURAND, Gilbert. As estruturas antropológicas do imaginário. São Paulo: Martins Fontes, 1997.

GARCIA, Nelson Jahr. O que é propaganda ideológica. 10. ed. São Paulo: Brasiliense, 1982.

GOMES, Wilson. Theathrum Politicum: a encenação política na sociedade dos mass mídias. In: FAUSTO NETTO, Antônio; BRAGA, José Luiz; PORTO, Sérgio Dayrell (Org.). A Encenação dos Sentidos: mídia, cultura e política. Rio de Janeiro: Diadorim, 1995.

HOPKINS, Claude. A ciência da propaganda. São Paulo: Cultrix, 1966.

JUNG, Carl Gustav. Os arquétipos e o inconsciente coletivo. Petrópolis: Vozes, 2008.

O Homem e seus símbolos. Rio de Janeiro: Nova Fronteira, 2008.

LAPLANTINE, Francois; TRINDADE, Liana. O que é imaginário. 1. ed. São Paulo: Brasiliense, 1996.

LIMA, Marcelo O. Coutinho. Marketing eleitoral. E-Book, 2002. Disponível em: <http://midiaexterna.wordpress. com/2008/05/21/marketing-eleitoral-por-marcelo-o-coutinho-de-lima>.

MARX, Karl. O capital: crítica da economia política. São Paulo: Nova Cultural, 1996. v. 1, livro 1: O processo de produção do capital.

MORAES, Denis de. O imaginário vigiado. A imprensa comunista e o realismo socialista no Brasil (1947-53). Rio de Janeiro: José Olympio, 1994. 
NICHOLS, Bill. Introdução ao documentário. Campinas, SP: Papirus, 2005.

PEREIRA, Wagner Pinheiro. Cinema e propaganda política no fascismo, nazismo, salazarismo e franquismo. Revista História: Questões \& Debates, Curitiba, n. 38, p. 101-131, 2003.

QUEIROZ, Adolpho. Reflexos fascistas da propaganda política no Brasil. In: QUEIROZ, Adolpho (Org.). Marketing político brasileiro. Piracicaba: Intercom/Cátedra da Unesco, 2004.

QUEIROZ, Adolpho et al. De Quintino Bocaiúva a Duda Mendonça: breve história dos marqueteiros políticos no Brasil republicano. In: QUEIROZ, Adolpho; MANHANELLI Carlos; BAREL, Moisés Stefano (Org.). Marketing Político, do comício à Internet. São Paulo: ABCOP - Associação Brasileira de Consultores Políticos, 2007.

ROCHA, Daniela; FRANCO, Lincoln. A importância do cinejornal na campanha eleitoral de Getúlio Vargas em 1950. São Bernardo do Campo: UMESP, 2007.

SOUZA, Carlos Roberto de. A fascinante aventura do cinema brasileiro. São Paulo: Cinemateca Brasileira, 1981.

SOUZA, Rose Mara Vidal de; GALINDO, Daniel. Mito, simbolismo e outros ingredientes do marketing político. São Bernardo do Campo: UMESP, 2010.

SOUZA, Rose Mara Vidal de. A imprensa na Segunda Guerra Mundial. Texto apresentado à disciplina de Marketing Político Internacional, ministrada pelo professor Doutor Adolpho Queiroz, no mestrado em Comunicação Social da Universidade Metodista de São Paulo (UMESP), São Bernardo do Campo, 2010.

TCHAKHOTINE, Serge. A mistificação das massas pela propaganda política. Rio de Janeiro: Civilização Brasileira, 1967. VEBLEN, Thorstein. A teoria da classe ociosa: um estudo econômico das instituições. São Paulo: Abril Cultural, 1983.

\section{FILMOGRAFIA}

JANGO: como, quando e porque se depõe um presidente da República. Direção de Sílvio Tendler. Roteiro de Sílvio Tendler. Texto de Mauricio Dias. Produção de Denize Goulart e Hélio Paulo Ferraz. Rio de Janeiro: Caliban Produções, 1984. DVD (117 min). 